\title{
Implementasi Metode TOPSIS Untuk Menentukan Karyawan Terbaik Berbasis Web Pada PT. Mun Hean Indonesia
}

\author{
Andrian Muljadi, Ali Khumaidi, Nuke L Chusna \\ Program Studi Teknik Informatika, Fakultas Teknik, Universitas Krisnadwipayana \\ Jakarta, Indonesia, Telp. (021) 8462229 \\ e-mail: andrianmuliadi@gmail.com, alikhumaidi@unkris.ac.id, nukelchusna@unkris.ac.id
}

\begin{abstract}
Abstrak
Dalam penentuan karyawan terbaik menjadi hal yang sulit bagi setiap perusahaan dikarenakan dalam melakukan penilaian harus berlandaskan kepada kriteria yang telah disetujui oleh masing-masing perusahaan. Banyak ditemukan pada saat penentuan karyawan terbaik kendala yang dialami adalah melakukan penilaian absensi saja tanpa melihat kriteriakriteria lain yang ada. Permasalahan pada PT. Mun Hean Indonesia adalah sulitnya pengambilan keputusan yang dilakukan secara manual mengingat setiap individu memiliki kepentingan sendiri dalam mengisi penilaian terhadap karyawan. Oleh sebab tersebut dibutuhkan sistem yang terkomputerisasi sehingga mampu menentukan karyawan terbaik menggunakan metode TOPSIS (Technique for Order Preference by Similarity to Ideal Solution) untuk melakukan pemeringkatan alternatif-alternatif mana yang memiliki nilai tertinggi sehingga dapat digunakan oleh perusahaan untuk memberikan hadiah atau kenaikan jabatan kepada karyawan terpilih dari hasil penilaian yang diberikan oleh sistem perusahaan.
\end{abstract}

Kata kunci: SPK, TOPSIS, Algoritma, Aplikasi, Karyawan Terbaik

\begin{abstract}
In determining the best employee is difficult for every company because in making an assessment must be based on criteria that have been agreed by each company. Many are found when determining the best employee the obstacle experienced is to assess attendance without looking at other existing criteria. Problems at PT. Mun Hean Indonesia is the difficulty of making decisions manually because each individual has his own interest in filling in an assessment of employees. Therefore we need a computerized computer system that can determine the best employees using the TOPSIS (Technique for Order Preference by Similarity to Ideal Solution) method to rank alternatives which have the highest value so that companies can use to give gifts or promotions to selected employees from the results of assessments provided by the company system.
\end{abstract}

Keywords : SPK, TOPSIS, Algorithms, Applications, Best Employees

\section{Pendahuluan}

Sumber Daya Manusia (SDM) merupakan komponen penting dari perusahaan. Pengelolaan Sumber Daya Manusia (SDM) dalam suatu perusahaan mempunyai peran yang besar untuk mempengaruhi banyak lingkup dalam meraih kesuksesan bisnis dari perusahaan tersebut. Jika perusahaan dapat mengelola Sumber Daya Manusia (SDM) dengan baik perusahaan juga dapat melakukan semua proses bisnis di dalamnya juga dengan baik [1].

Selama ini proses administrasi kepegawaian/HRD di PT. Mun Hean Indonesia masih berjalan secara konvensional, baik dalam hal data karyawan, data promosi/demosi/mutasi, data PHK, data sanksi, data training, sistem pengajuan cuti dan izin karyawan, data dinas luar, juga dalam hal penentuan karyawan terbaik perusahaan. Hal tersebut menjadi suatu permasalahan dikarenakan lamanya waktu yang dibutuhkan di dalam proses konvensional tersebut, sering tidak tercatatnya atau tercecernya proses administrasi dan sulitnya dalam melihat, mengambil dan melakukan monitoring data dan informasi [2].

Penentuan karyawan terbaik perusahaan menjadi fokus utama pada penelitian ini dikarenakan dalam mengambil keputusan terhadap penentuan karyawan terbaik di PT. Mun 
Hean Indonesia masih menerapkan sistem yang manual. Dengan sistem manual tersebut membuat lamanya proses untuk menentukan karyawan terbaik dikarenakan banyaknya jumlah karyawan yang akan dinilai dan berbanding terbalik dengan sedikitnya jumlah di bagian HRD yang melakukan perhitungan secara manual. Selain itu kendala lainnya adalah penilai terkadang memiliki preferensi tersendiri dalam melakukan penilaian [3]. PT. Mun Hean Indonesia mempunyai beberapa ketentuan sebagai tolak ukur penilaian. Tolak ukur tersebut mengacu pada kedisiplinan, hasil kerja, pengetahuan, sikap dan kerjasama. Demi tercapainya hasil yang memuaskan bagi perusahaan juga karyawan maka pengambilan keputusan yang cepat dan tepat sangat dibutuhkan.

Penelitian sebelumnya yang juga membahas metode TOPSIS yaitu: "Sistem Rekomendasi Pemilihan Karyawan Terbaik dengan Metode TOPSIS pada Bussan Auto Finance", kesimpulan yang didapat dari penelitian ini adalah perancangan dengan menggunakan metode TOPSIS dapat digunakan untuk kasus pemilihan karyawan terbaik, lalu dengan diterapkannya sistem rekomendasi pemilihan karyawan terbaik menggunakan metode TOPSIS di Bussan Auto Finance menjadikan penilaian kinerja karyawan jauh lebih efektif yaitu dari segi waktu karena mempercepat proses dan membuat hasil yang diinginkan lebih tepat [1]. Selanjutnya "Implementasi Metode TOPSIS untuk Penilaian Kinerja Pegawai (Studi Kasus Kelurahan Rejosari Barat)", penelitian ini juga mendapat hasil bahwa proses penilaian kinerja pegawai dapat berjalan dengan lebih cepat dengan adanya sistem penilaian yang sudah terkomputerisasi dengan menggunakan metode TOPSIS [4]. Dan penelitian lainnya yaitu "Sistem Pendukung Keputusan Penilaian Pegawai Terbaik di Rumah Sakit Umum Hidayah Purwokerto Menggunakan Metode TOPSIS", hasil dari penelitian ini yaitu metode TOPSIS dapat digunakan untuk memberikan penilaian dengan cepat dan tepat dibandingkan perhitungan secara manual [5]. Sedangkan pembeda penelitian ini dengan penelitian sebelumnya yaitu pada penelitian ini akan dibangun suatu aplikasi yang mengimplementasikan metode TOPSIS untuk merekomendasikan karyawan terbaik berbasis web dengan framework terkini yaitu Codelgniter 4.0, lalu penelitian ini juga akan mengintegrasikan Sistem Pendukung Keputusan untuk menentukan karyawan terbaik dengan sistem informasi kepegawaian di PT. Mun Hean Indonesia sehingga data alternatif yang dibutuhkan otomatis ditarik langsung dari data karyawan yang telah diklasifikasi sebelumnya yaitu karyawan dengan status karyawan tetap dengan jenjang staff (non-management \& non-supervisor) sehingga tidak perlu lagi menambah satu per-satu data alternatif yang membuat proses menjadi lama, selain itu terdapat menu untuk menambah, mengubah dan menghapus kriteria dan bobot kriteria dimana mengingat kemungkinan untuk bertambahnya kriteria yang menjadi aspek penilaian sangat mungkin terjadi.

Berdasarkan permasalahan dan penelitian di atas, maka diperlukan penerapan atau implementasi metode TOPSIS dalam bentuk suatu aplikasi Sistem Pendukung Keputusan (SPK) berbasis web untuk menentukan karyawan terbaik. Pada penelitian ini penulis akan menggunakan metode TOPSIS. Alasan penulis menggunakan metode ini adalah dikarenakan metode ini menggunakan proses pemeringkatan dan pembobotan, serta memiliki konsep yang simple dan mudah dipahami juga dalam hal penulisan pengkodeannya sangat efisien [6]. Maka diharapkan nantinya nilai yang dihasilkan akan jauh lebih cepat dan tepat karena telah didasarkan pada perhitungan nilai kriteria dan bobot yang telah ditentukan, sehingga didapatkan output hasil yang lebih akurat dibandingkan dengan perhitungan manual [7].

\section{Metodologi Penelitian}

Penelitian ini dilakukan di PT. Mun Hean Indonesia, proses dalam mengumpulkan data dan informasi penulis lakukan dengan cara pendekatan deskriptif atau survey dimana artinya penulis melakukan pengumpulan data dari beberapa karyawan, supervisor/kepala bagian dan bagian HRD PT. Mun Hean Indonesia yang digunakan sebagai acuan untuk menilai kinerja dan penentuan karyawan terbaik perusahaan. Sebagai uji coba penelitian ini dilakukan dengan karyawan PT. Mun Hean Indonesia dengan status karyawan tetap, dengan jenjang staff (nonmanagement dan non-supervisor).

\subsection{Tahapan Penelitian}

Tahapan penelitian tentang Implementasi Metode TOPSIS Untuk Menentukan Karyawan Terbaik Berbasis Web Pada PT. Mun Hean Indonesia dilakukan sebagai berikut: 


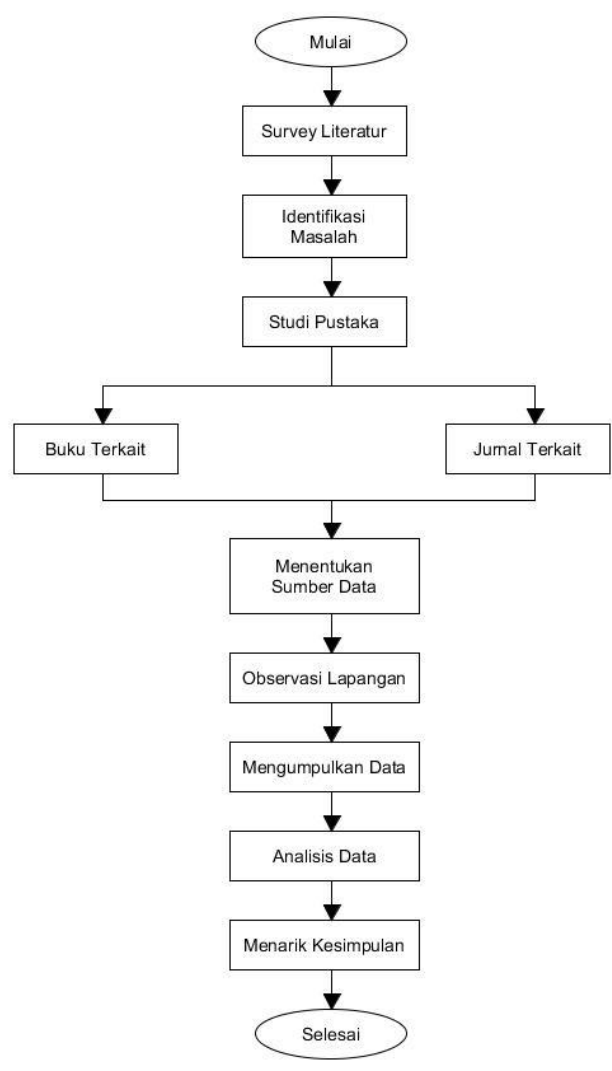

Gambar 1. Flowchart Tahapan Penelitian

Berikut ini adalah penjelasan dari flowchart di atas:

1. Survey Literatur

Pada Tahapan ini, penulis akan mengumpulkan referensi dari beberapa studi terdahulu serta beberapa informasi yang berkaitan dengan topik yang penulis pilih.

2. Identifikasi Masalah

Melakukan identifikasi dari masalah yang akan dibahas nantinya. Juga mempunyai keterkaitan dengan Implementasi Metode TOPSIS Untuk Menentukan Karyawan Terbaik Berbasis Web berdasarkan studi terdahulu dan informasi yang diperoleh.

3. Studi Pustaka

Membaca dan menganalisis studi terdahulu berupa buku-buku atau jurnal-jurnal penelitian yang berkaitan dengan Sistem Pendukung Keputusan (SPK) dan Metode Technique for Order Preference by Similarity to Ideal Solution (TOPSIS) yang akan digunakan sebagai bahan teori dalam penelitian.

4. Menentukan Sumber Data

Pada tahapan ini penulis akan menentukan beberapa sumber data yang digunakan dalam penelitian ini, seperti data primer dan dan sekunder. Data primer yang dibutuhkan berasal langsung dari objek penelitian di perusahaan. Data ini penulis peroleh langsung dari PT. Mun Hean Indonesia. Data di peroleh dengan cara wawancara langsung dengan karyawan, kepala bagian/supervisor dan bagian HRD PT. Mun Hean Indonesia. Kemudian data sekunder yang penulis peroleh berasal secara tidak langsung yaitu merupakan data yang sudah diolah maupun telah menjadi kutipan ataupun suatu informasi, seperti dari internet, jurnal, paper, buku serta berbagai studi terdahulu yang berkaitan dengan penelitian yang penulis pilih.

5. Observasi Lapangan

Untuk melakukan observasi lapangan, peneliti secara langsung datang ke PT. Mun Hean Indonesia di daerah Jakarta Barat dan meminta izin kepada pihak-pihak yang berwenang dan terkait untuk melakukan penelitian.

6. Mengumpulkan Data 
Pada tahap ini penulis menyatukan data dan mewawancarai pihak terkait untuk mendapatkan hal-hal yang saling terhubung dengan penelitian ini, seperti data alternatif yang akan digunakan, kriteria untuk menentukan karyawan terbaik dan bobot dari tiap kriteria yang digunakan.

7. Analisis Data

Pada tahap ini penulis menganalisa dan melakukan pengolahan data yang didapat serta melakukan perhitungan dengan metode TOPSIS berdasarkan masing-masing kriteria terhadap alternatif yang ada.

8. Menarik Kesimpulan

Pada tahapan ini penulis menarik kesimpulan dengan dasar data-data yang telah di analisis pada bab-bab sebelumnya dan dilakukan pemeriksaan apakah kesimpulan yang didapat sudah sesuai dengan maksud dan tujuan dari penelitian ini. Selain itu penulis juga memberikan saran perbaikan dan pengembangan sebagai masukan bagi perusahaan untuk dapat diperbaiki atau dikembangkan ke depannya.

Sedangkan untuk tahapan dalam pengembangan sistem metode Waterfall versi Sommerville tahun 2011 dipakai pada penelitian ini.

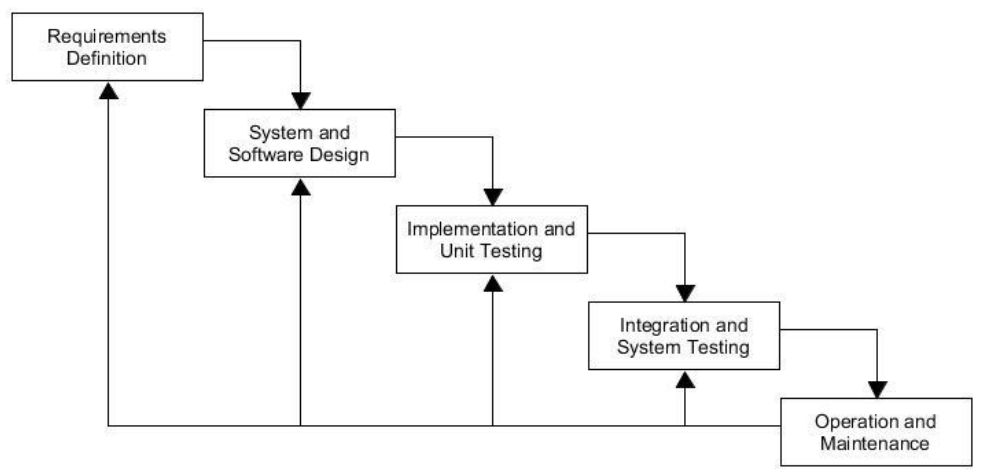

Gambar 2. Metode Waterfall Versi Sommerville (2011)

Berikut ini penjelasan dari tahapan-tahapan Metode Waterfall Versi Sommerville (2011):

1. Pendefinisian Kebutuhan

Tahap pertama ini dilakukan penentuan fitur sistem, analisa kebutuhan sistem, kendala saat membuat juga tujuan sistem yang akan dibangun melalui komunikasi dengan yang akan menggunakan sistem kemudian akan didefinisikan bagaimana spesifikasi sistem dengan rinci beserta dengan fungsi-fungsinya.

2. Desain Sistem dan Perangkat Lunak

Tahap kedua ini perancangan sistem dimulai dengan cara membagi kebutuhan menjadi beberapa bagian seperti perangkat keras dan lunak serta membuat arsitektur sistem secara menyeluruh.

3. Implementasi dan Uji Coba Unit

Tahap ketiga ini dilakukan perancangan perangkat lunak yang diimplementasikan sebagai sebuah unit utuh. Uji coba juga dilakukan dengan cara memverifikasi apakah setiap unit yang dibangun sudah cukup memenuhi kebutuhan dan persyaratannya.

4. Integrasi dan Uji Coba Sistem

Tahap keempat ini dimana unit yang telah menjadi aplikasi digabung menjadi sebuah sistem lengkap untuk memastikan bahwa aplikasi sudah sesuai dengan kebutuhan user. Setelah proses tersebut, sistem sudah dapat dikirimkan ke pengguna (user).

5. Operasi dan Perbaikan

Tahap kelima ini adalah tahap terlama dalam urutan pengembangan sistem. Setelah sistem diimplementasikan dan digunakan. Perbaikan sistem dilakukan terhadap kesalahan yang tidak ditemukan pada tahapan sebelumnya serta meningkatkan implementasi dari unit program dan membuat layanan sistem menjadi lebih baik lagi.

\section{$2.2 \quad$ Tahapan Metode TOPSIS}

Langkah-langkah dalam metode TOPSIS diurutkan seperti ini: 

a. Membuat matriks keputusan
b. Membuat matriks keputusan ternormalisasi
c. Membuat matriks keputusan ternormalisasi terbobot
d. Menentukan matriks solusi ideal positif dan negatif
e. Menentukan jarak solusi ideal positif dan negatif
f. Menentukan nilai preferensi

\section{Kajian Pustaka}

Kajian pustaka pada penelitian ini memuat tentang studi literatur yang menjadi referensi penelitian ini. Beberapa materi yang dimuat diantaranya adalah Sistem Pendukung Keputusan (SPK) dan Metode TOPSIS.

\subsection{Sistem Pendukung Keputusan}

Sistem Pendukung Keputusan (SPK) secara umum merupakan suatu sistem informasi terkomputerisasi dan interaktif, sistem informasi ini melakukan pengolahan data dengan cara memberikan sebuah solusi dari banyak masalah yang tidak teratur sehingga dapat menarik kesimpulan dalam bentuk informasi yang dapat digunakan untuk mengambil keputusan [8]. Kemampuan intelektual seseorang akan dipadukan dengan kemampuan berpikir komputer untuk menghasilkan hasil yang lebih tepat. Pada hal pengambilan keputusan menerapkan proses dimana pemilihan sebuah tindakan diantara banyak pilihan yang tersedia, sehingga tujuan yang telah di tentukan sebelumnya dapat dicapai.

\subsection{TOPSIS}

TOPSIS yang memiliki kepanjangan Technique for Order Preference by Similarity to Ideal Solution merupakan salah satu metode pengambilan keputusan multi kriteria yang dapat diandalkan untuk menentukan suatu kasus yang ada berdasarkan proses minimalisasi stimultan dari suatu titik jarak ideal dan berdasarkan proses maksimalisasi jarak dari suatu titik terendah [9].

Secara umum, metode TOPSIS mempunyai prosedur dalam tahapan prosesnya yaitu seperti berikut ini:

a. Membuat matriks keputusan ternormalisasi

b. Membuat matriks keputusan ternormalisasi terbobot

c. Menentukan matriks solusi ideal positif dan negatif

d. Menentukan jarak solusi ideal positif dan negatif

e. Menentukan nilai preferensif

Metode ini membutuhkan nilai kerja setiap alternatif $A_{i j}$ terhadap setiap kriteria $C_{j}$ yang ternormalisasi seperti pada persamaan 1 berikut:

$$
\begin{aligned}
& \mathrm{r}_{\mathrm{ii}}=\frac{x_{\text {ii }}}{\sum_{\mathrm{i}=1}^{\mathrm{n} x_{\mathrm{i}}}} \text {, dengan } \mathrm{i}=1,2, \ldots, \mathrm{m} \text {; dan } \mathrm{j}=1,2, \ldots, \mathrm{n} \\
& \text { Dimana: } \\
& \mathrm{I}_{\text {iij }} \quad=\text { Matriks ternormalisasi [i] [j] } \\
& \mathrm{x}_{\mathrm{ij}} \quad=\text { Matriks keputusan [i] [i] }
\end{aligned}
$$

Selanjutnya solusi ideal positif $\mathrm{A}^{+}$dan solusi ideal negatif $\mathrm{A}^{-}$dapat ditentukan berdasarkan rating bobot ternormalisasi $\left(\mathrm{y}_{\mathrm{i}}\right)$ seperti pada persamaan 2, 3 dan 4 berikut:

$$
\begin{aligned}
& y_{i j}=w_{i} r_{i} \text {, dengan } \mathrm{i}=1,2, \ldots, n \\
& A^{+}=\left(y^{+} 1, y^{+} 2, \ldots, y^{+} n\right) \\
& A^{-}=\left(y^{-1} 1, y^{-2}, \ldots, y^{-n} n\right) \\
& \text { Dimana: } \\
& \mathrm{y}_{\text {ij }} \quad=\text { Matriks ternormalisasi terbobot [i] [j] } \\
& \mathrm{w}_{\mathrm{i}} \quad=\text { Vektor bobot [i] } \\
& \mathrm{y}^{+} \mathrm{j} \quad=\operatorname{Max}_{\mathrm{ij}} ; \text { jika } \mathrm{j} \text { adalah atribut benefit (keuntungan) } \\
& =\operatorname{Min} \mathrm{y}_{\mathrm{ij}} ; \text { jika } \mathrm{j} \text { adalah atribut cost (biaya) }
\end{aligned}
$$




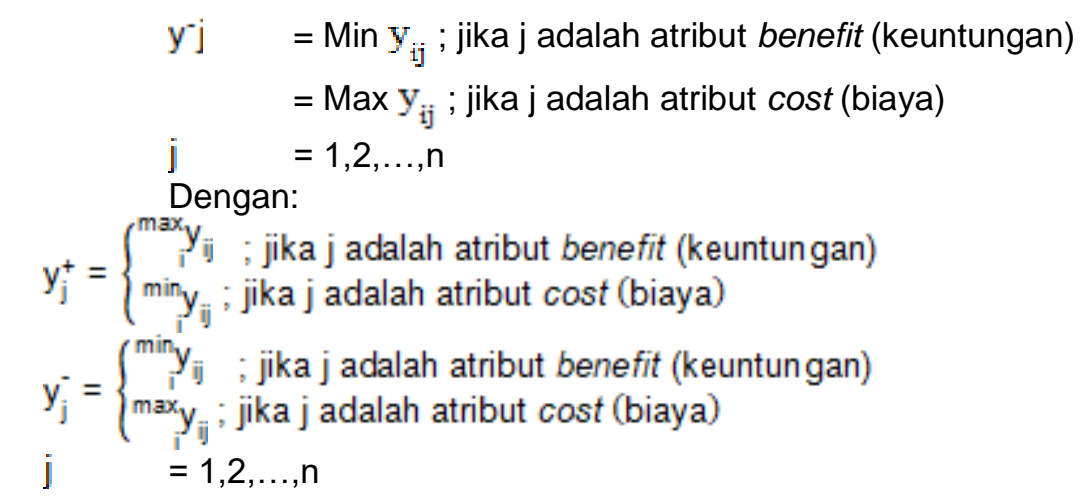

Lalu jarak antara alternatif $A_{1}$ dengan solusi ideal positif dirumuskan seperti pada persamaan 7 berikut:

$D_{i}^{*}=\sqrt{\sum_{i=0}^{n}\left(y_{i}+-y_{i j}\right) 2}$, dengan $i=1,2, \ldots n$

Dimana:

$\mathrm{D}_{i^{*}} \quad=$ Jarak alternatif dengan solusi ideal positif

$y_{\text {iij }} \quad=$ Matrik normalisasi terbobot [i] [j]

$\mathrm{y}_{i^{*}} \quad=$ Solusi ideal positif [i]

Selanjutnya jarak antara alternatif $A_{1}$ dengan solusi ideal negatif dirumuskan seperti pada persamaan 8 berikut:

$D_{i=}=\sqrt{\sum_{j=1}^{n}\left(y_{i j}-y_{i}\right) 2}$, dengan $i=1,2, \ldots m$

Dimana:

$\mathrm{D}_{\mathrm{i}} \quad=$ Jarak alternatif dengan solusi ideal negatif

$y_{\text {ij }} \quad=$ Matrik normalisasi terbobot [i] [i]

$y_{\hat{i}} \quad=$ Solusi ideal negatif [i]

$V_{1}=\frac{D_{i}}{D_{i}+D_{i}+}$, dengan $i=1,2, \ldots, m$

Nilai $V_{1}$ yang lebih besar menunjukan bahwa alternatif $A_{1}$ lebih dipilih.

Dimana:

$V_{1} \quad=$ Jarak terdekat antara setiap alternatif dengan solusi ideal

$\mathrm{D}_{i^{*}} \quad=$ Jarak setiap alternatif dengan solusi ideal positif

$\mathrm{D}_{\overline{\mathrm{i}}} \quad=$ Jarak setiap alternatif dengan solusi ideal negatif

\section{Hasil dan Pembahasan}

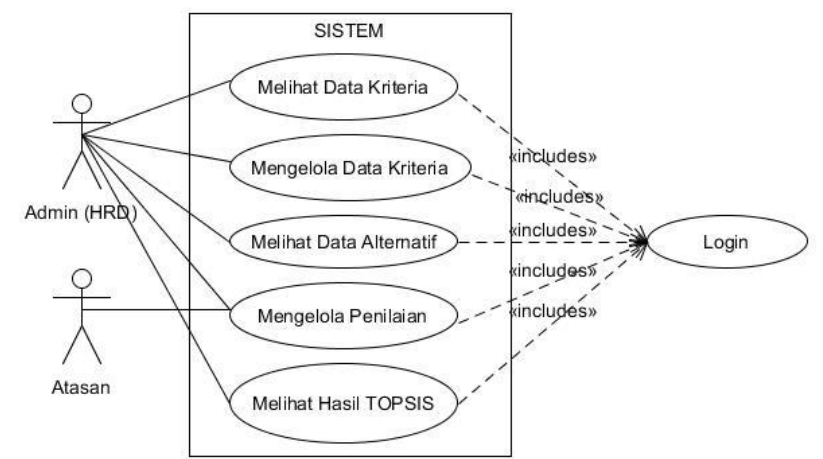

Gambar 3. Use Case Diagram 
Berdasarkan data observasi yang telah didapat, maka pada tahap ini akan dilakukan pembahasan dengan cara pengujian perhitungan. Dalam pengujian perhitungan ini peneliti mengambil 20 data untuk di ujicoba dan akan dinilai berdasarkan bobot kriteria yang dimiliki menggunakan metode TOPSIS, yaitu A01 - A20.

Setelah data alternatif ditentukan selanjutnya dilakukan penentuan kriteria.

Tabel 1. Kriteria

\begin{tabular}{cc}
\hline Kriteria & Keterangan \\
\hline CR001 & Kedisplinan \\
CR002 & Hasil Kerja \\
CR003 & Pengetahuan \\
CR004 & Sikap \\
CR005 & Kerjasama \\
\hline
\end{tabular}

Lalu setelah menentukan kriteria, selanjutnya tentukan range penilaian dengan nilai 1 sampai 5, seperti berikut ini:

Tabel 2. Range Penilaian

\begin{tabular}{cc}
\hline Range Penilaian & Nilai \\
\hline $0-20$ (Buruk) & 1 \\
$21-40$ (Sangat Kurang) & 2 \\
$41-60$ (Kurang) & 3 \\
$61-80$ (Baik) & 4 \\
$81-100$ (Sangat Baik) & 5 \\
\hline
\end{tabular}

Setelah itu, tentukan tingkat kepentingan atau bobot kriteria (W) dari masing-masing kriteria yang ada, pada studi kasus di PT. Mun Hean Indonesia, perusahaan telah menyetujui dan menggunakan bobot dari masing-masing kriteria yaitu sebagai berikut:

Tabel 3. Bobot Setiap Kriteria

\begin{tabular}{ccc}
\hline Kriteria & Keterangan & Bobot \\
\hline CR001 & Kedisplinan & 3 \\
CR002 & Hasil Kerja & 2 \\
CR003 & Pengetahuan & 2 \\
CR004 & Sikap & 2 \\
CR005 & Kerjasama & 1 \\
\hline
\end{tabular}

Berdasarkan beberapa tabel di atas, maka disusun atau ditetapkan tabel Nilai Matriks Keputusan yaitu sebagai berikut:

Tabel 4. Nilai Matriks Keputusan

\begin{tabular}{cccccc}
\hline Alternatif & \multicolumn{5}{c}{ Kriteria } \\
\cline { 2 - 6 } & CR001 & CR002 & CR003 & CR004 & CR005 \\
\hline A01 & 5 & 4 & 4 & 3 & 2 \\
A02 & 5 & 2 & 3 & 4 & 4 \\
A03 & 3 & 3 & 5 & 4 & 3 \\
A04 & 4 & 4 & 3 & 2 & 2 \\
A05 & 5 & 4 & 3 & 3 & 4 \\
A06 & 4 & 3 & 3 & 4 & 4 \\
A07 & 4 & 3 & 3 & 4 & 5 \\
A08 & 5 & 4 & 4 & 3 & 3 \\
A09 & 4 & 3 & 3 & 4 & 3 \\
A10 & 3 & 5 & 4 & 2 & 2 \\
A11 & 3 & 4 & 3 & 2 & 2 \\
A12 & 2 & 4 & 3 & 3 & 5 \\
A13 & 4 & 3 & 3 & 3 & 3 \\
A14 & 4 & 3 & 3 & 5 & 4 \\
\hline
\end{tabular}




\begin{tabular}{cccccc}
\hline Alternatif & \multicolumn{5}{c}{ Kriteria } \\
\cline { 2 - 6 } & CR001 & CR002 & CR003 & CR004 & CR005 \\
\hline A15 & 1 & 3 & 3 & 4 & 3 \\
A16 & 4 & 3 & 3 & 2 & 3 \\
A17 & 5 & 4 & 3 & 4 & 3 \\
A18 & 5 & 4 & 3 & 4 & 2 \\
A19 & 5 & 4 & 3 & 4 & 3 \\
A20 & 5 & 4 & 2 & 5 & 4 \\
\hline
\end{tabular}

Selanjutnya data tersebut akan diproses menggunakan metode TOPSIS untuk dapat mencari tau siapa yang akan menjadi karyawan terbaik perusahaan dengan bobot kriteria (W) yang sudah ditentukan yaitu $\mathrm{W}=(3,2,2,2,1)$. Berdasarkan rumus metode TOPSIS yang telah dijelaskan di atas, maka diperoleh matriks ternormalisasi (Matriks $\mathrm{R}$ ) dan matriks ternormalisasi terbobot (Matriks $\mathrm{Y}$ ) yang merupakan perkalian antara Matriks $\mathrm{R}$ dengan bobot setiap kriteria adalah sebagai berikut:

$\mathrm{R}=\left[\begin{array}{ccccc}0,26958 & 0,24759 & 0,27472 & 0,18787 & 0,13423 \\ 0,26958 & 0,1238 & 0,20604 & 0,25049 & 0,26846 \\ 0,16175 & 0,1857 & 0,3434 & 0,25049 & 0,20135 \\ 0,21567 & 0,24759 & 0,20604 & 0,12524 & 0,13423 \\ 0,26958 & 0,24759 & 0,20604 & 0,18787 & 0,26846 \\ 0,21567 & 0,1857 & 0,20604 & 0,25049 & 0,26846 \\ 0,21567 & 0,1857 & 0,20604 & 0,25049 & 0,33558 \\ 0,26958 & 0,24759 & 0,27472 & 0,18787 & 0,20135 \\ 0,21567 & 0,1857 & 0,20604 & 0,25049 & 0,20135 \\ 0,16175 & 0,30949 & 0,27472 & 0,12524 & 0,13423 \\ 0,16175 & 0,24759 & 0,20604 & 0,12524 & 0,13423 \\ 0,10783 & 0,24759 & 0,20604 & 0,18787 & 0,33558 \\ 0,21567 & 0,1857 & 0,20604 & 0,18787 & 0,20135 \\ 021567 & 0,1857 & 0,20604 & 0,31311 & 0,26846 \\ 0,05392 & 0,1857 & 0,20604 & 0,25049 & 0,20135 \\ 0,21567 & 0,1857 & 0,20604 & 0,12524 & 0,20135 \\ 0,26958 & 0,24759 & 0,20604 & 0,25049 & 0,20135 \\ 0,26958 & 0,24759 & 0,20604 & 0,25049 & 0,13423 \\ 0,26958 & 0,24759 & 0,20604 & 0,25049 & 0,20135 \\ 0,26958 & 0,24759 & 0,13736 & 0,31311 & 0,26846\end{array}\right]$


Selanjutnya, didapat Solusi Ideal Positif dan Negatif sebagai berikut:

$\begin{array}{cccccc}\text { I } & \text { CR001 } & \text { CR002 } & \text { CR003 } & \text { CR004 } & \text { CR005 } \\ \text { Positif } & 0,80875 & 0,61898 & 0,6868 & 0,62622 & 0,33558 \\ \text { Negatif } & 0,16175 & 0,24759 & 0,27472 & 0,25049 & 0,13423\end{array}$

Lalu, didapat Jarak Solusi Ideal Positif dan Negatif sebagai berikut:

$\begin{array}{ccc}I & \text { Positif } & \text { Negatif } \\ \text { A01 } & 0,37078 & 0,75569 \\ \text { A02 } & 0,48331 & 0,71989 \\ \text { A03 } & 0,44683 & 0,59753 \\ \text { A04 } & 0,54651 & 0,56182 \\ \text { A05 } & 0,39755 & 0,72972 \\ \text { A06 } & 0,42793 & 0,59197 \\ \text { A07 } & 0,42263 & 0,6107 \\ \text { A08 } & 0,33905 & 0,75867 \\ \text { A09 } & 0,44344 & 0,58044 \\ \text { A10 } & 0,55248 & 0,56396 \\ \text { A11 } & 0,61414 & 0,42991 \\ \text { A12 } & 0,6237 & 0,40319 \\ \text { A13 } & 0,40919 & 0,53838 \\ \text { A14 } & 0,76752 & 0,65487 \\ \text { A15 } & 0,56756 & 0,3185 \\ \text { A16 } & 0,35284 & 0,52361 \\ \text { A17 } & 0,38343 & 0,75235 \\ \text { A18 } & 0,35284 & 0,74935 \\ \text { A19 } & 0,35284 & 0,75235 \\ \text { A20 } & 0,43548 & 0,79944\end{array}$

Terakhir didapat Nilai Preferensi untuk setiap alternatif, yaitu sebagai berikut:

Tabel 5. Nilai Preferensi

\begin{tabular}{cccc}
\hline No. & Peringkat ke- & Nama Alternatif & Nilai Preferensi \\
\hline 1 & 1 & A08 & 0,6911 \\
2 & 2 & A19 & 0,6807 \\
3 & 3 & A17 & 0,6807 \\
4 & 4 & A01 & 0,6708 \\
5 & 5 & A18 & 0,6615 \\
6 & 6 & A20 & 0,6474 \\
7 & 7 & A05 & 0,6473 \\
8 & 8 & A14 & 0,6154 \\
9 & 9 & A02 & 0,5983 \\
10 & 10 & A07 & 0,591 \\
11 & 11 & A06 & 0,5804 \\
12 & 12 & A03 & 0,5721 \\
13 & 13 & A09 & 0,5669 \\
14 & 14 & A13 & 0,5217 \\
15 & 15 & A04 & 0,5069 \\
16 & 16 & A10 & 0,5051 \\
17 & 17 & A16 & 0,4799 \\
18 & 18 & A11 & 0,4118 \\
19 & 19 & A12 & 0,3926 \\
20 & 20 & A15 & 0,2933 \\
\hline
\end{tabular}

Berdasarkan perhitungan dengan metode Technique for Order Preference by Similarity to Ideal Solution (TOPSIS) maka didapat bahwa alternatif dengan peringkat ke-1 atau yang terpilih menjadi karyawan terbaik perusahaan yaitu alternatif A08 dengan nilai preferensi sebesar 0,6911 . 
Hasil Tampilan User Interface dari implementasi metode TOPSIS untuk menentukan karyawan terbaik dapat dilihat pada gambar berikut:

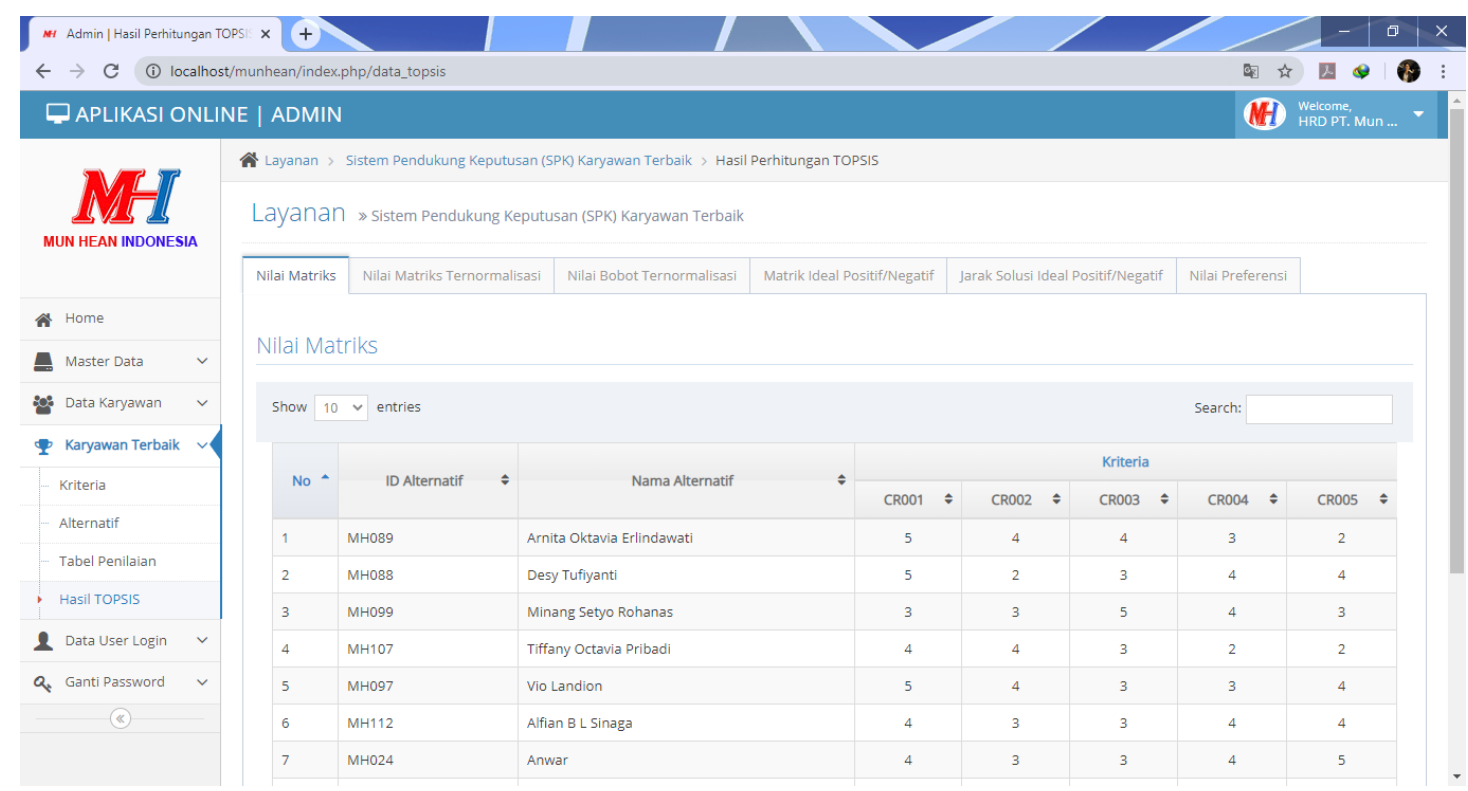

Gambar 4. Tampilan User Interface Nilai Matriks
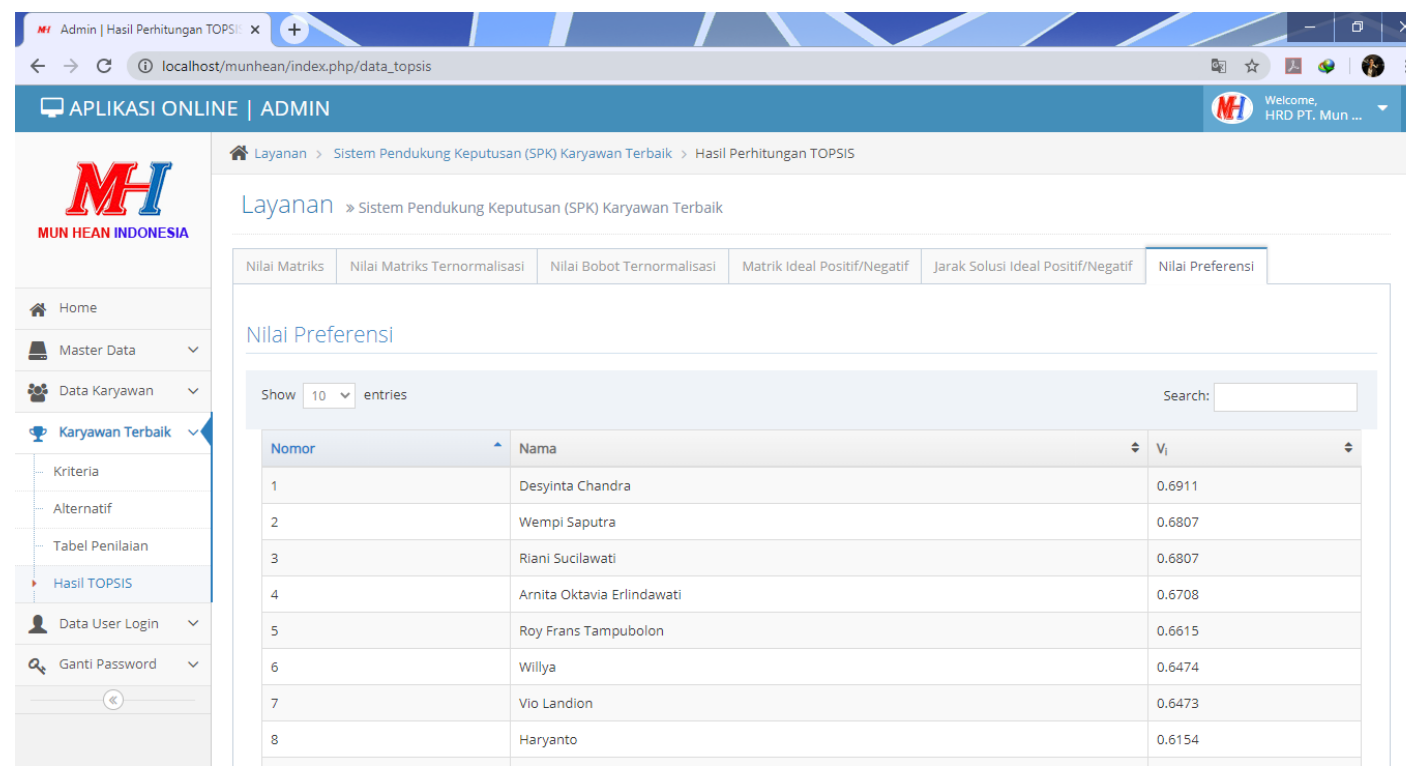

₹ Layanan > Sistem Pendukung Keputusan (SPK) Karyawan Terbaik > Hasil Perhitungan TOPSIS

Layanan » Sistem Pendukung Keputusan (SPK) Karyawan Terbaik

\begin{tabular}{|l|l|l|l|ll}
\hline Nilai Matriks & Nilai Matriks Ternormalisasi & Nilai Bobot Ternormalisasi & Matrik Ideal Positif/Negatif & Jarak Solusi Ideal Positif/Negatif & Nilai Preferensi
\end{tabular}

Nilai Preferens

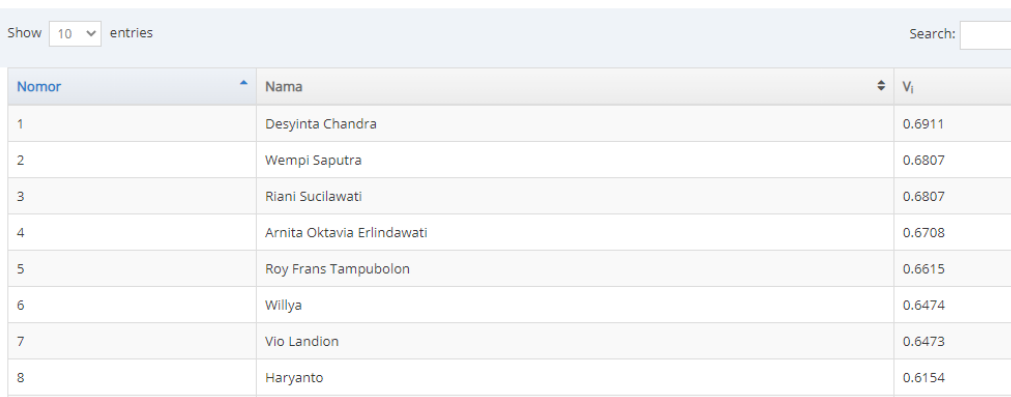

Gambar 5. Tampilan User Interface Nilai Preferensi

Setelah metode TOPSIS di jalankan untuk menentukan karyawan terbaik perusahaan, selanjutnya adalah tahap evaluasi terhadap sistem terkomputerisasi yang mengimplementasikan metode TOPSIS di dalamnya menggunakan lembar kuesioner.

Tabel 6. Bobot Nilai Jawaban

Jawaban Bobot

\begin{tabular}{lc}
\multicolumn{1}{c}{ Jawaban } & Bobot \\
\hline (A) Sangat Mudah/Bagus/Sesuai/Jelas & 5 \\
(B) Mudah/Bagus/Sesuai/Jelas & 4 \\
(C) Netral & 3 \\
(D) Cukup Sulit/Bagus/Sesuai/Jelas & 2 \\
(E) Sangat Sulit/Jelek/Tidak Sesuai/Tidak & 1 \\
Jelas & \\
\hline
\end{tabular}


Selanjutnya, berikut adalah hasil dari tahap evaluasi:

Tabel 7. Hasil Evaluasi

\begin{tabular}{|c|c|c|c|c|c|c|c|c|c|c|c|}
\hline \multirow[t]{2}{*}{ No } & \multirow[t]{2}{*}{ Pertanyaan } & \multicolumn{4}{|c|}{ Jawaban } & & \multicolumn{5}{|c|}{ Presentase } \\
\hline & & $\mathrm{A}$ & $\mathrm{B}$ & $\mathrm{C}$ & {[} & & $\bar{A}$ & $B$ & $\mathrm{C}$ & $\mathrm{D}$ & $E$ \\
\hline 1 & $\begin{array}{l}\text { Apakah penggunaan metode } \\
\text { TOPSIS untuk menentukan } \\
\text { karyawan terbaik perusahaan } \\
\text { dirasa adil dan transparan? }\end{array}$ & 9 & 1 & 0 & ( & & $\begin{array}{l}90 \\
\%\end{array}$ & $\begin{array}{l}10 \\
\%\end{array}$ & $0 \%$ & $0 \%$ & $0 \%$ \\
\hline 2 & $\begin{array}{l}\text { Apakah dengan sistem yang } \\
\text { terkomputerisasi } \\
\text { memudahkan untuk menilai } \\
\text { dan menentukan karyawan } \\
\text { terbaik perusahaan? }\end{array}$ & 9 & 1 & 0 & ( & & $\begin{array}{l}90 \\
\%\end{array}$ & $\begin{array}{l}10 \\
\%\end{array}$ & $0 \%$ & $0 \%$ & $0 \%$ \\
\hline 3 & $\begin{array}{l}\text { Apakah aplikasi yang } \\
\text { dibangun untuk menentukan } \\
\text { karyawan terbaik } \\
\text { menggunakan metode } \\
\text { TOPSIS berjalan lancar dan } \\
\text { penempatan tombol dan } \\
\text { navigasi sesuai dengan } \\
\text { kemauan pengguna? }\end{array}$ & 8 & 2 & 0 & ( & & $\begin{array}{l}80 \\
\%\end{array}$ & $\begin{array}{l}20 \\
\%\end{array}$ & $0 \%$ & $0 \%$ & $0 \%$ \\
\hline
\end{tabular}

Tabel 8. Presentasi Hasil Evaluasi

\begin{tabular}{|c|c|c|c|c|c|c|c|}
\hline \multirow[t]{2}{*}{ No } & \multirow[t]{2}{*}{ Pertanyaan } & \multicolumn{5}{|c|}{ Nilai } & \multirow[t]{2}{*}{ Jml } \\
\hline & & $A \times 5$ & $\mathrm{Bx} 4$ & $\mathrm{C} \times 3$ & Dx2 & Ex1 & \\
\hline 1 & $\begin{array}{l}\text { Apakah penggunaan metode } \\
\text { TOPSIS untuk menentukan } \\
\text { karyawan terbaik perusahaan dirasa } \\
\text { adil dan transparan? }\end{array}$ & 45 & 4 & 0 & 0 & 0 & 49 \\
\hline 2 & $\begin{array}{l}\text { Apakah dengan sistem yang } \\
\text { terkomputerisasi ini memudahkan } \\
\text { untuk menilai dan menentukan } \\
\text { karyawan terbaik perusahaan? }\end{array}$ & 45 & 4 & 0 & 0 & 0 & 49 \\
\hline 3 & $\begin{array}{l}\text { Apakah aplikasi yang dibangun } \\
\text { untuk menentukan karyawan terbaik } \\
\text { menggunakan metode TOPSIS } \\
\text { berjalan lancar dan penempatan } \\
\text { tombol dan navigasi sesuai dengan } \\
\text { kemauan pengguna? }\end{array}$ & 40 & 8 & 0 & 0 & 0 & 48 \\
\hline
\end{tabular}

Kesimpulan Evaluasi:

a. Pertanyaan ke-1

Dari hasil di atas didapat bahwa dari 10 responden untuk pertanyaan pertama adalah 49. Nilai rata-ratanya adalah $49 / 10=4.9$. Presentase nilainya adalah $4.9 / 5 \times 100=$ $98 \%$.

b. Pertanyaan ke-2

Dari hasil di atas didapat bahwa dari 10 responden untuk pertanyaan kedua adalah 49 .

Nilai rata-ratanya adalah $49 / 10=4.9$. Presentase nilainya adalah $4.9 / 5 \times 100=98 \%$.

c. Pertanyaan ke-3

Dari hasil di atas didapat bahwa dari 10 responden untuk pertanyaan ketiga adalah 48 .

Nilai rata-ratanya adalah $48 / 10=4.8$. Presentase nilainya adalah $4.8 / 5 \times 100=96 \%$.

Berdasarkan evaluasi yang telah dilakukan dapat ditarik kesimpulan bahwa penerapan/implementasi metode TOPSIS di PT. Mun Hean Indonesia diterima dengan baik dikarenakan memudahkan perusahaan dalam menentukan karyawan terbaik serta aplikasi yang dibangun juga sudah sesuai dengan kemauan pengguna. 


\section{Kesimpulan}

Penelitian ini menghasilkan sebuah aplikasi Sistem Pendukung Keputusan (SPK) yang dapat menentukan karyawan terbaik pada PT. Mun Hean Indonesia berdasarkan kriteria kedisiplinan, hasil kerja, pengetahuan, sikap dan kerjasama menggunakan metode TOPSIS. Telah dilakukan uji coba dengan memasukkan sampel data karyawan kemudian sistem berhasil mengolah data tersebut kurang dari 1 detik sehingga terbukti sistem ini dapat melakukan perhitungan lebih cepat dibandingkan dengan perhitungan secara manual. Dari data yang dimasukkan terpilihlah 1 orang karyawan terbaik PT. Mun Hean Indonesia yaitu A08 dengan nilai preferensi sebesar 0,6911 .

\section{Daftar Pustaka}

[1] Bany Setiadji and Sofa Sofiana, "Sistem Rekomendasi Pemilihan Karyawan Terbaik Dengan Metode Topsis Pada Bussan Auto Finance," J. Inform. Univ. Pamulang, vol. 1, no. sistem rekomendasi, pp. 12-16, 2016.

[2] N. W. Wisswani, N. M. Karmiathi, I. Bagus, and B. Harta, "Aplikasi Biro Jasa Pengurusan Pengajuan Visa Berbasis Web," vol. 8, no. 1, pp. 1-12, 2020.

[3] Y. Malau, "Implementasi Metode Simple Additive Weighting Untuk Sistem Pendukung Keputusan Penentuan," Paradigma, vol. 19, no. 1, pp. 38-45, 2017.

[4] D. Tamara, "IMPLEMENTASI METODE TOPSIS UNTUK PENILAIAN KINERJA PEGAWAI (Studi Kasus Kelurahan Rejosari Barat) Destian," pp. 1-42, 2019.

[5] P. Priambadha and H. Mustafidah, "Sistem Pendukung Keputusan Penilaian Pegawai Terbaik di Rumah Sakit Umum Hidayah Purwokerto Menggunakan Metode TOPSIS ( Decision Support System Ratings for Best Employee in General Hospital," vol. 15, no. 2, pp. 119-130, 2018.

[6] I. Herman Firdaus, G. Abdillah, F. Renaldi, and U. Jenderal Achmad Yani JI, "Sistem Pendukung Keputusan Penentuan Karyawan Terbaik Menggunakan Metode Ahp Dan Topsis," Semin. Nas. Teknol. Inf. dan Komun., vol. 2016, no. Sentika, pp. 2089-9815, 2016.

[7] H. Hertyana, "Sistem Pendukung Keputusan Penentuan Karyawan Terbaik Menggunakan Metode Saw Studi Kasus Amik Mahaputra Riau," J. Intra-Tech, vol. 2, no. 1, pp. 73-82, 2018.

[8] A. A. Chamid, "Penerapan Metode Topsis Untuk Menentukan Prioritas Kondisi Rumah," Simetris J. Tek. Mesin, Elektro dan Ilmu Komput., vol. 7, no. 2, p. 537, 2016.

[9] S. O. K. Reflin Yadi, Muhammad Sobri, "Implementasi metode topsis untuk menentukan karyawan terbaik di pt.kfc cabang demang," Implementasi Metod. Topsis Untuk Menentukan Karyawan Terbaik Di Pt.Kfc Cab. Demang, pp. 1-9, 2015. 